\section{Summary}

The administration of chloroquine to patients with symptomatic porphyria causes a transient reaction in which pyrexia and malaise are accompanied by a marked increase in urine porphyrin excretion. The excretion of porphyrin precursors, $\delta$-aminolaevulinic acid and porphobilinogen increases only slightly.

This reaction is associated with clinical and biochemical evidence of liver damage, in particular, a rise in serum glutamic oxaloacetic transaminase activity. It is thought that the porphyrin excreted in the urine is released from the liver.

After the reaction patients are not affected by further administration of chloroquine; it is not known for how long this refractory state persists. The reaction resembles in some ways the primaquine-induced haemolysis of red cells deficient in glucose-6-phosphate dehydrogenase.

Patients with symptomatic porphyria have improved clinically after chloroquine therapy, but this is attributed to other factors; evidence of hepatic dysfunction argues against the use of chloroquine in this condition.

We are indebted to Dr. C. J. Uys, of the department of histopathology, University of Capetown, for examining the liver biopsies, and to the department of chemical pathology for routine chemicopathological data. The assistance of Mrs. M. J. Levey in the estimation of quantitative porphyrins in urine and faeces is gratefully acknowledged.
This work was supported in part by a grant, P.H.S. A-3997, from the National Institute of Arthritis and Metabolic Diseases, Public Health Service, U.S.A. It formed part of the programme of the C.S.I.R./U.C.T. Renal-Metabolic Research Group.

\section{REPERENCES}

Alving, A. S., Eichelberger, L., Craige, B., Jones, R., Whorton, C. M., and Pullman, T. N. (1948). F. clin. Invest., Suppl. to vol. 27, p. 60 . Berliner, R. W., Earle, D. P, Taggart, J. V., Zubrod, C. G., Welch, W. J., Conan, N. J., Bauman, E., Scudder, S. T., and Shannon, J. A. (1948). Ibid., p. 98.

Cann, H. M., and Verhulst, H. L. (1961). Pediatrics, 27, 95

Cripps, D. J., and Curtis, A. C. (1962). Arch. Derm., 86, 575.

Dresel, E. I. B., Rimington, C., and Tooth, B. E. (1956). Scand. 7. clin. Lab. Invest., 8, 73 .

Eales, L. (1961). Ann. Rev. Med., 12, 251.

Dowdle, E. B., and Sweeney, G. D. (editors) (1963). Proceedings of the International Conference on the Porphyrias, S.A. F. Lab. clin. Med., 9, 301 .

Embree, P. W. (1961). Cent. Afr. F. med., 7, 450.

Eriksen, L. (1953). Scand. \%. clin. Lab. Invest., 5, 155.

Holti, G., Rimington, C., Tate, B. C., and Thomas, G. (1958). Quart. 7. Med., 27, 1 .

Kautz, H. D. (1959). f. Amer. med. Ass., 171, 1504.

Linden, I. H., Steffen, C. G., Newcomer, V. D., and Chapman, M. (1954). Calif. Med., 81, 235 .

Mauzerall, D., and Granick, S. (1956). 7. biol. Chem., 219, 435.

Rimington, C., and Sveinsson, S. L. (1950). Scand. F. clin. Lab. Invest., 2, 209.

Sweeney, G. D., Levey, M., Dowdle, E. B., and Eales; L. (1962). S. Afr. Med. 7., 36, 312 .

Teodorescu, S., Badaniou, A., and Gheorghiu, G. (1959). Derm. Wschr., $139,445$.

With, T. K. (1956). Scand. 7. clin. Lab. Invest., 8, 113.

Woods, S. M., Peters, H. A., and Johnson, S. A. M. (1958). Arch. Derm., 77, 559.

\title{
Significance of the Extensor Plantar Response in Surgery of Parkinson's Disease
}

\author{
A. G. L. CORKILL,* M.A., M.B., B.CHIR. ; A. H. CHIGNELL,* M.B., B.S.
}

Brit. med. F., 1965, 1, 1285-1286

Parkinsonian patients showing an extensor plantar response rather than a flexor plantar response are often regarded as having more widespread disease. This is true in that the pyramidal system is being secondarily involved. That a worse prognosis is thereby indicated is, however, not so certain. Nevertheless, the presence of extensor plantar responses is often cited as a relative contraindication to surgery.

The supposed grounds for contraindication appear to be twofold: firstly, patients with extensor plantar responses are thought to have a relatively worse prognosis in any case owing to the more widespread disease, and, secondly, there is a special danger-that of pseudobulbar palsy.

Damage to the internal capsule or other parts of the pyramidal system is an unavoidable occurrence in a small proportion of operative procedures for Parkinsonism. It is supposed that cases already showing involvement of the pyramidal system, as evidenced by extensor plantar responses, will be especially prone to developing pseudobulbar palsy.

It has been observed that a certain number of Parkinsonian patients with extensor plantar responses have concomitant cervical spondylosis or encephalitis (Brain, 1962).

To examine the post-operative prognosis of patients with and without extensor plantar responses who also had widespread

* The National Hospital for Nervous Diseases, Queen Square, London. manifestations of the disease was the purpose of the present review.

\section{Present Investigation}

Clinical Material.-A group of 112 Parkinsonian patients were reviewed, representing all the cases considered as inpatients for operation by Mr. Harvey Jackson at the National Hospital, Queen Square, in the years 1959 to 1961. Of these 112 , 38 were abstracted on the basis of showing widespread manifestations of Parkinson's disease. The remaining 74 patients, who as a group were generally less affected with Parkinsonism, are not further considered here. Widespread manifestations of Parkinson's disease were taken arbitrarily to be, in addition to tremor and rigidity of all four limbs, at least two of the following features: poor voice and speech change, facial akinesia, poor convergence, chairborne existence, tremor of midline structures-that is, jaw, tongue, head, or trunk-and oculogyric crises. Of the 38 patients showing widespread manifestations of the disease, eight had extensor plantar responses on one side and seven had bilateral extensor plantar responses. All 38 were operated on.

Operative Treatment.-This involved the making of a lesion under radiological and electro-stimulatory control in the ventrolateral nucleus of the thalamus. A stiff paste of Etopalin and 
kaolin was injected in increments of $0.2 \mathrm{ml}$. up to a total of $2 \mathrm{ml}$. The actual volume of the lesion was adjusted at operation according to its effect on tremor and rigidity shown in the patient.

Classification at Three-year Follow-up.-All patients were seen three years post-operatively and evaluated from three particular aspects: social state, widespread manifestations of the disease, and evidence of pseudobulbar palsy. The social state was considered in three classes- " $A$ " at work (doing full housework if a woman), " B " at home but requiring some help, and " $\mathrm{C}$ " institutionalized. Widespread manifestations were considered as a group, but significant deterioration in any one of them was recorded as deterioration of the whole group. Pseudobulbar evidence, dysarthria, monotony of voice, and dysphagia were treated similarly in that deterioration in one feature was recorded as deterioration for the whole group. Changes (usually deterioration) in these three aspects were compared between two groups of patients, these two groups being those who had an extensor plantar response, whether unilaterally or bilaterally, and those who had not. Furthermore, an endeavour was made to establish the relation between extensor plantar responses and obvious post-encephalitic cases. The criteria for the presence of encephalitis at some stage were histories of prolonged pyrexial episodes, preferably with some degree of depression of conscious level, long histories, and other recognized signs of encephalitis-for example, loss of accommodation, sialorrhoea, oculogyric crises, and hyperhidrosis. The

TABLE I.-Summary of Results

\begin{tabular}{|c|c|c|c|c|c|}
\hline \multirow{2}{*}{ Change } & & \multicolumn{2}{|c|}{ Extensor Plantar Response } & \multicolumn{2}{|c|}{ Flexor Plantar Response } \\
\hline & & No. & $\%$ & No. & $\%$ \\
\hline \multicolumn{6}{|c|}{ Changes in Social Status } \\
\hline $\begin{array}{l}\text { Improved } \\
\text { No change } \\
\text { Worse }\end{array}$ & $\begin{array}{l}. \\
\because \\
\mid\end{array}$ & $\begin{array}{l}2 \\
9 \\
4\end{array}$ & $\begin{array}{l}13 \\
60 \\
27\end{array}$ & $\begin{array}{r}3 \\
12 \\
8\end{array}$ & $\begin{array}{l}13 \\
54 \\
35\end{array}$ \\
\hline \multicolumn{6}{|c|}{ Changes in Widespread Manifestations } \\
\hline $\begin{array}{l}\text { Improved } \\
\text { No change } \\
\text { Worse }\end{array}$ & $\ddot{.}$ & $\begin{array}{l}0 \\
9 \\
6\end{array}$ & $\begin{array}{l}0 \\
60 \\
40\end{array}$ & $\begin{array}{l}1 \\
12 \\
10\end{array}$ & $\begin{array}{l}52 \frac{1}{2} \\
53\end{array}$ \\
\hline \multicolumn{6}{|c|}{ Changes in Pseudobulbar Palsy } \\
\hline $\begin{array}{l}\text { Improved } \\
\text { No change } \\
\text { Worse }\end{array}$ & $\because$. & $\begin{array}{r}0 \\
12 \\
3\end{array}$ & $\begin{array}{l}0 \\
80 \\
20\end{array}$ & $\begin{array}{r}0 \\
15 \\
8\end{array}$ & $\begin{array}{l}0 \\
65 \\
35\end{array}$ \\
\hline
\end{tabular}

Table II.-Alteration in Pseudobulbar Palsy Features in Seven Patients with Bilateral Extensor Responses Pre-operatively

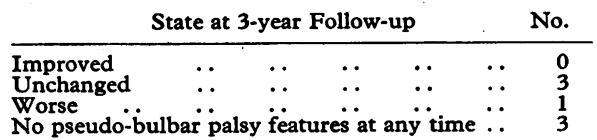

TABLE III.-Relation of Plantar Response to Type of Disease

\begin{tabular}{|c|c|c|c|c|}
\hline \multirow{2}{*}{ Type } & \multicolumn{2}{|c|}{$\begin{array}{c}\text { Extensor Plantar } \\
\text { Response } \\
\end{array}$} & \multicolumn{2}{|c|}{$\begin{array}{c}\text { Flexor Plantar } \\
\text { Response }\end{array}$} \\
\hline & No. & $\%$ & No. & $\%$ \\
\hline $\begin{array}{lll}\begin{array}{l}\text { Post-encephalitic } \\
\text { Other }\end{array}{ }^{\prime . .} & . .\end{array}$ & $\begin{array}{l}9 \\
6\end{array}$ & $\begin{array}{l}60 \\
40\end{array}$ & $\begin{array}{l}11 \\
12\end{array}$ & $\begin{array}{l}48 \\
52\end{array}$ \\
\hline
\end{tabular}

incidence of worsening of pseudobulbar features was investigated in those patients showing bilateral extensor plantar responses.

Results.-These are summarized in Tables I to III. No patients developed cervical spondylosis complications sufficiently severe to merit cervical surgery.

\section{Discussion}

In a predominantly extrapyramidal disease the presence of pyramidal signs could reasonably be taken as indicating significant spread and a worse prognosis. Examination after a threeyear post-operative period did not substantiate this. Cooper (1961a) states that there is a twofold relationship of pseudobulbar palsy to Parkinsonism. Firstly, it should constitute a contraindication to surgery, and, secondly, it may occur after bilaterally symmetrical operations for Parkinsonism.

In the cases of this series the features of pseudobulbar palsy were made worse in $20 \%$ of those showing extensor plantar responses as opposed to $35 \%$ of those with flexor responses. Even cases with bilateral extensor plantar responses showed only one out of seven which suffered deterioration of pesudobulbar features as a result of operation and three-year passage of time. It is evident in this series, therefore, that the dangers of developing pseudobulbar palsy are somewhat exaggerated. Furthermore, an extensor plantar response is not a bad prognostic sign, nor can it be cited as a contraindication to surgery.

In agreement with the findings of Cooper (1961b) and of Gillingham (1960) this group of patients, all of whom were extensively affected by Parkinsonism, showed a poor response to surgery.

\section{Summary}

Of 112 patients with Parkinsonism, 38 were found to have widespread manifestations in addition to tremor and rigidity of all four limbs. Of these 38, 15 had extensor plantar responses, 8 unilaterally and 7 bilaterally. At three-year followup post-operatively there was no significant difference between the group with extensor plantar responses and those with flexor responses. The relation between extensor plantar responses, encephalitis, and the cervical spondylosis was briefly examined.

Our thanks are due to Mr. Harvey Jackson for his advice and kind permission to use cases under his care and to Dr. J. A. V. Bates for his advice.

\section{REFERENCES}

Brain, W. R. (1962). Diseases of the Nervous System, 6th ed., p. 476. Oxford Univ. Press, London.

Cooper, I. S. (1961a). Parkinsonism, Its Medical and Surgical Therapy. p. 61. Springfield, Ill. Blackwell, Oxford. (1961b). Ibid., p. 18.

Gillingham, F. J., Watson, W. S., Donaldson, A. A., and Naughton, J. A. L. (1960). Brit. med. f., 2, 1395. 